\title{
ANALISIS KECENDERUNGAN PENELITIAN MAHASISWA JURUSAN BAHASA DAN SASTRA ARAB FAKULTAS BAHASA DAN SENI UNIVERSITAS NEGERI JAKARTA
}

\author{
Chakam Failasuf* \\ *Dosen Tetap Jurusan Bahasa dan Sastra Arab FBS UNJ \\ Email : chakamfa@gmail.com
}

\begin{abstract}
ABSTRAK
Penelitian ini membahas bagaimana mahasiswa JBSA memilih topik skripsi yang ditulisnya, dengan penjelasan beberapa bahasan topik penelitian, jenis penelitian, dan kecenderungan penelitian.

Skripsi yang dihasilkan JBSA dalam kurun waktu 5 tahun tersebut tersebar dalam berbagai bidang kajian penelitian, yang meliputi; penelitian kualitatif sejumlah 151 buah skripsi, penelitian kuantitatif sejumlah 100 buah skripsi, penelitian tindakan 62 buah skripsi,dan makalah ujian komprehesif 8 buah makalah. Penelitian mahasiswa JBSA yang dihasilkan dari penelitian kualitatif sejumlah 151 buah itu berupa analisis isi dari gejala bahasa atau hasil karya sastra yang dikaji melalui kajian teoretik gejala atau fenomena bahasa, dari penelitian kuantitatif menghasilkan 100 buah yaitu $31 \%$ tersebut berupa kajian uji korelasional 40 buah skripsi, uji eksperimen 35 buah skripsi, dan uji kausal komparatif menghasilkan 25 buah skripsi. Sedangkan Penelitian tindakan hanya 2 macam tindakan yaitu penggunaan media pembelajaran dan penggunaan metode dalam pembelajaran, Pembelajaran sejumlah 35 buah skripsi dan dalam penggunaan metode pembelajaran menghasilkan 27 buah skripsi Dari hasil pembahasan, bila dilihat dari rasio hasil skripsi yang dihasilkan setiap semester terhadap penerimaan mahasiswa setiap tahun, Jurusan Bahasa dan Sastra masih menunjukkan angka keberhasilan yang diperoleh $\pm 90 \%$. perolehan ini menunjukkan bahwa sebaran mata kuliah setiap semester memungkinkan bagi mahasiswa untuk menyelesaikan masa studi tepat waktu yaitu dalam waktu 8 semester, sehingga JBSA secara akreditasi dapat dinilai berhasil.

Variasi dan sebaran kajian mahasiswa dalam penelitian sudah cukup merata dalam berbagai jenis penelitian, baik itu penelitian kualitatif maupun kuantitatif ataupun penelitian tindakan.. Dengan demikian mahasiswa JBSA telah memenuhi kriteria dalam memilih topik penelitian sesuai dengan ketertarikan dan kemampuan mereka. bila dilihat dari jenis penelitian kualitatif masih dalam taraf analisis deskriptif dan kuantitatif masih dalam uji analisis, baik kuantitatif maupun kualitaif belum sampai pada taraf uji prediksi ataupun aplikasi, sehingga masih memungkinkan seorang mahasiswa memperdalam penelitian dari penelitian yang sudah dilakukan oleh mahasiswa sebelumnya.
\end{abstract}

Kata kunci : Skripsi, Topik Penelitian, Jenis Penelitian, dan Kecenderungan Penelitian 


\section{PENDAHULUAN}

Mahasiswa berasal dari kata maha yang berarti besar atau tinggi dan siswa yang berarti pelajar atau dengan kata lain mahasiswa adalah pelajar yang berada pada strata tertinggi. Berdasarkan peraturan pemerintah RI No. 30 tahun 1990 mahasiswa adalah peserta didik yang terdaftar dan belajar di perguruan tinggi tertentu. Chaerul (Senjaya, 2010) mengungkapkan bahwa mahasiswa memiliki peran penting sebagai agen perubahan (agent of change) bagi tatanan kehidupan yang secara realistis dan logis diterima oleh masyarakat. Mahasiswa diharapkan mampu menerapkan dan mengaplikasikan pengetahuan yang telah diperolehnya selama menempuh proses pembelajaran di perguruan tinggi, sehingga dapat memberikan manfaat bagi masyarakat luas. Mahasiswa pada tahap perkembangannya digolongkan ke dalam fase dewasa awal atau berada pada rentang usia $18-24$ tahun (Hurlock, 1980). Individu yang berada pada masa dewasa awal mengalami perubahan dari mencari pengetahuan menjadi menerapkan pengetahuan untuk mengejar karir. Perubahan tersebut kemudian disebut oleh Schaie (Santrock, 1995) sebagai fase pencapaian prestasi (achieving stage) atau suatu fase di masa dewasa awal yang melibatkan penerapan intelektualitas pada situasi yang memiliki konsekuensi besar dalam mencapai tujuan jangka panjang, seperti pencapaian karir dan pengetahuan. Penerapan intelektualitas pada seorang dewasa dapat dilakukan pada bidang bidang vokasional atau bidang pendidikan. Adapun jenjang yang dapat ditempuh sebelum menapaki bidang pekerjaan dan untuk mendalami suatu bidang tertentu adalah dengan menempuh proses pendidikan di perguruan tinggi. Sebelum meraih gelar sarjana, terlebih dahulu mahasiswa harus melalui proses pembelajaran di perguruan tinggi dan mengakhirinya dengan membuat tugas akhir berupa skripsi. Skripsi adalah tugas akhir mahasiswa jenjang $\mathrm{S} 1$, yang berupa kegiatan penelitian ilmiah secara kuntitatif maupun kualitatif yang pada garis besarnya meliputi kegiatan : latar belakang masalah, perumusan masalah, kajian teoretis, rancangan metodologi, pengumpulan data, analisis data, interprtasi, dan simpulan, (pedoman penulisan tugas akhir,2013) sebagai muara dari keseluruhan pengalaman belajarnya, didasarkan atas hasil penelitian lapangan, dan ditulis dengan tata cara penulisan karya ilmiah. Penyusunan skripsi tidaklah mudah, perlu pemahaman teori penelitian terutama yang berkaitan dengan penelitian untuk skripsi dan metodologi penelitian. Mahasiswa yang belum terbiasa untuk melakukan penelitian tentunya akan banyak mengalami kesulitan, terutama kaitannya dengan metodologi penelitian. Metodologi penelitian merupakan hal yang sangat penting dalam pembuatan skripsi maupun penelitian lainnya. Dalam metodologi penelitian untuk skripsi terdapat beberapa subbab yang mencerminkan bagaimana penelitian atau laporan skripsi tersebut dibuat, di antaranya adalah jenis penelitian yang mahasiswa pilih dan gunakan. Jenis penelitian biasanya mewakili bentuk dan metodologi penelitian. Mahasiswa di masing-masing program studi memiliki kecenderungan yang berbeda dalam memilih jenis penelitian yang akan digunakan dalam pembuatan dan penyusunan skripsi. Banyak faktor yang mempengaruhi kecenderungan mahasiswa dalam memilih jenis penelitian yang akan digunakan dan terkadang kesenjangan kecenderungan ini sangat signifikan sekali.

Skripsi berisi kajian terhadap masalah-masalah keilmuan sesuai dengan bidang studi masing-masing yang berguna, baik bagi pengembangan ilmu maupun bagi pemecahan masalah-masalah nyata yang dihadapi. Melalui pembuatan skripsi, mahasiswa diharapkan mampu menuangkan gagasan dan mengaplikasikan pengetahuan yang telah diperolehnya selama berkuliah, sehingga mampu memberikan manfaat konkret bagi masyarakat sesuai dengan bidang garapannya.

Skripsi hingga saat ini dikenal sebagai wujud karya ilmiah seorang mahasiswa, sekaligus sebagai wujud 
pertanggungjawaban hasil studi selama mahasiswa menempuh kuliah. Hingga saat ini pun, skripsi masih menjadi tolok ukur lulus atau tidaknya seorang mahasiswa untuk mendapatkan gelar sarjana. Pembuatan skripsi membantu mahasiswa untuk bisa berpikir logis dan sistematis. Tujuan diterapkannya ketentuan itu supaya mahasiswa yang sudah menuntut ilmu dari semester pertama hingga akhir bisa menerapkan secara langsung, yaitu; ilmu, materi, dan teori yang didapatkan selama kuliah. Skripsi merupakan mata kuliah wajib yang harus ditempuh mahasiswa sebagai tugas akhir dalam memperoleh gelar sarjana, dan mata kuliah ini merupakan tolok ukur untuk menyelesaikan jenjang pendidikan S1. Penulisan skripsi ini bertujuan memberikan bekal dan wawasan kepada mahasiswa mengenai keterampilan melakukan penelitian, agar mahasiswa memiliki pengalaman dalam memecahkan masalah dengan menggunakan prosedur penelitian ilmiah,(pedoman Penulisan Tugas akhir, 2013) sesuai dengan bidang jurusan selama kuliah, begitu juga Jurusan Bahasa dan Sastra Arab memberikan syarat kepada mahasiswanya untuk menulis skripsi berbahasa Arab yang merupakan spesialisasi bidang kuliah mereka.

Pada dasarnya mahasiswa diberikan waktu untuk menyelesaikan skripsi dalam waktu satu semester atau enam bulan masa kuliah. Hanya saja kenyataannya banyak mahasiswa yang membutuhkan waktu lebih dari enam bulan untuk penyelesaian skripsi, sehingga yang terjadi kemudian adalah keterlambatan dalam penyelesaian studi (congestion) dan tidak jarang berujung pada pengeluaran mahasiswa (drop out), Karena masa belajar telah habis. Ironisnya hal tersebut kini menjadi hal yang lumrah terjadi hampir di setiap perguruan tinggi. Hal ini terjadi karena banyak hal, salah satunya dikarenakan mahasiswa mengalami kesulitan mencari judul sebagai objek kajian penelitiannya. Kesulitan ini membuat mahasiswa cenderung untuk membaca dan meniru skripsi ataupun penelitian sebelumnya. Sebagian besar mahasiswa menunjukkan fokus penelitiannya mengerucut pada bidang tertentu saja atau bahkan memilih tema yang sama dari skripsi karya mahasiswa angkatan sebelumnya.

Kecenderungan mahasiswa mencari dan merujuk skripsi hasil karya angkatan sebelumnya ini menyebabkan tema penelitian di bidang pendidikan bahasa lainnya kurang menjadi perhatian mahasiswa, karena hanya terbatas pada bidang tertentu saja, padahal masih banyak bidang bidang yang lain yang bersifat inovatif dan layak untuk diteliti sebagai fenomena baru dalam bidang pendidikan, dan kurang adanya informasi yang memadai dari ranah penelitian yang bisa digarap mahasiswa dalam penulisan skripsi. Dengan demikian dapat menyebabkan mahasiswa sulit mencari judul baru. Dari kondisi yang terjadi sselama ini peneliti berusaha membantu mahasiswa memetakan kajian penelitian yang ada pada skripsi khususnya di jurusan Bahasa dan Sastra Arab FBS UNJ agar dapat memberikan wacana penelitian apa saja akan diteliti dalam penulisan skripsi. Dan pada penelitian ini bisa dijadikan alat penunjang peningkatan akreditasi Jurusan dalam mengarahkan mahasiswa dan memberi informasi untuk bisa tepat waktu sesuai dengan masa studi mahasiswa S1.

\section{Rumusan Masalah}

Bertolak dari latar belakang di atas dapat dirumuskan penelitian ini :

1. Bidang apa sajakah yang paling banyak diteliti mahasiswa JBSAselama kurun 5 tahun terakhir?

2. Bidang mana saja yang masih bisa dijadikan penelitian lanjutan pada skripsi yang sudah ada?

\section{Tujuan Penelitian}

Adapun tujuan penelitian adalah :

1. Agar bisa memetakan jenis penelitian yang sudah diteliti mahasiswa JBSA.

2. Agar bisa mengarahkan mahasiswa mencari kajian dalam penelitian untuk bisa segera menyelesaikan skripsinya.

\section{Manfaat Penelitian}

Dari penelitian dapat dimanfaatkan oleh Jurusan Bahasa dan Sastra Arab sebagai 
rujukan untuk mengarahkan kepada mahasiswa terhadap penelitian yang akan dilaksanakan, sehingga tidak terjadi penumpukan topic masalah dan kesamaan kajin dalam penulisan skripsi mahasiswa

Dari penelitian ini juga Jurusan Bahasa dan Sastra Arab dapat melihat hasil pemetaan karya ilmiah dalam berbagai kajian penelitian dari hasil penulisan mahasisawa JBSA yang bisa dijadikan rujukan akreditasi jurusan.

\section{KECENDERUNGAN PENELITIAN MAHASISWA}

Pada penelitian ini akan membahas bagaimana mahasiswa memilih topik skripsi yanga akan ditulisnya, oleh karena itu akan dijelaskan beberapa bahasan topik penelitian, jenis penelitian, dan kecenderungan penelitian

\section{TOPIK PENELITIAN}

Topik biasanya diidentifikasikan berdasarkan pengalaman, observasi pada seting penelitian, dan bacaan tentang tentang topik tersebut (Emzir, 2010). Memilih topik penelitian dalam proses penelitian adalah tahap awal yang harus dilakukan seorang peneliti sebelum memulai melakukan rentetan kegiatan penelitian berikutnya. Tanpa didahului dengan penentuan topik yang jelas, rinci, dan layak diteliti, tahaptahap berikutnya pada proses penelitian yang dilakukan niscaya tidak akan berkembang, sekadar mengikuti perkembangan data di lapangan, tetapi tidak menjawab secara mendalam topik penelitian yang telah dirumuskan Walaupun dalam permulaan penelitian adalah masalah, hal itu harus ditentukan secara jelas dan tepat berkaitan dengan topik atau bidang apa. Memilih salah satu topik penelitian (research topic) kadangkadang juga disebut sebagai fokus studi, ideide penelitian, masalah penelitian merupakan langka awal yang dilakukan ketika mempersiapkan suatu rencana penelitian.

Topik penelitian merupakan konsep utama yang dibahas dalam suatu penelitian dan penulisan ilmiah. Selain itu, topik juga merupakan konsep sentral yang dijelaskan dalam studi (sering dipertukarkan dengan judul penelitian) dan sangat penting kedudukannya dalam penelitian (Silalahi, 2010). Topik, fokus atau isu-isu penelitian merupakan wilayah umum dari penelitian. Biasanya para peneliti mengggunakan isu-isu teoritis umum dan hal-hal praktis atau yang membingungkan secara empiris sebagai sumber dari topik. Topik penelitian dapat muncul dari tinjauan literatur secara ekstensif, dianjurkan oleh brekan, peneliti atau pembimbing atau dikembangkan oleh pengalaman nyata. Dari manapun sumber topik diperoleh, namun keputusan dan penentuan terakhir adalah terletak pada mahasiswa sendiri. Oleh karena itu, sebelum topik ditentukan, ada beberapa hal yang perlu dipertimbangkan (Narbuko dan Achmadi, 2009), yaitu:

\section{a. Apakah topik tersebut dapat dijangkaunya, dikuasainya (manageable topic)}

Manageble topic berarti mempunyai kesanggupan dan menguasai pokok masalah. Suatu penelitian tidak akan berhasil dengan memuaskan apabila peneliti tidak mempunyai bekal pengetahuan dan kecakapan tentang cara-cara mencari data dan mengelola data yang telah terkumpul. Oleh sebab itu, ada ungkapan bahwa jangan sekali-kali melakukan sesuatu apa pun juga yang ada di luar jangkauan kemampuan dirinya sendiri". Dengan demikian, hal-hal yang perlu diperhatikan seperti di bawah ini.

1) Apakah latar belakang pengetahuan, kecakapan dan kemampuan diri sendiri, sudah cukup untuk memecahkan persoalan-persoalan yang berhubungan dengan topik yang akan dikerjakan?

2) Apakah waktu, dana, telah dipikirkan dengan masak dan mencukupi?

3) Apakah topik tersebut dapat memeroleh konsultan dan pembimbing dengan gampang?

4) Apakah tidak ada hambatan dari pihakpihak lain berkenaan dengan topik tersebut?

b. Apakah bahan-bahan/data-data tersedia secukupnya (obtinable data)

Obtainable data berarti mendapatkan data dan berlaku. Suatu topik yang sangat baik belum merupakan jaminan bahwa data- 
datanya akan tersedia atau tercukupi di dalam penelitiannya, sedangkan data sangat dibutuhkan dalam mengembangkan data dan menyusun hipotesis. Selanjutnya, untuk mengembangkan hipotesis juga tidak sematamata data saja yang dibutuhkan, tetapi juga buku-buku, buletin, majalah, koran, dan lain sebagainya sangat dibutuhkan sekali. Demikian pula untuk menguji kebenaran hipotesis, maka orang harus perlu ke lapangan atau kancah. Hal itu dikarenakan buku-buku bacaan dan teknik pengumpulan data yang valid (sahih) dan reliabel (dapat dipercaya), harus dikuasainya sebaikbaiknya.

\section{c. Apakah topik tersebut penting diteliti (significance of topic)}

Signifiancance of topic berarti topik yang dipilih itu haruslah bermakna atau penting. Oleh sebab itu, hal-hal yang perlu diperhatikan sebagai berikut.

1) Dapatkah pembahasan topik tersebut memberikan sumbangan yang cukup berarti bagi perkembangan ilmu pengetahuan yang sudah ada?

2) Apakah tidak mungkin bahwa penelitian tersebut hanya duplikasi saja?

3) Apakah mungkin penelitian tersebut memang merupakan pengecekan kembali daripada penelitian yang pernah diadakan atau pengujian ulangan?

4) Apakah topik tersebut betul-betul perlu diteliti, karena mempunyai kegunaan praktis bagi masyarakat dan lain sebagainya?

\section{d. Apakah topik tersebut cukup menarik minat untuk diteliti dan dikaji (interested topic)}

Interesting topic berarti topik yang dipilih menarik perhatian. Peneliti haruslah dapat membangkitkan semangat dan minatnya sendiri terhadap suatu topik yang akan diteliti atau dibahasnya. Tanpa adanya minat dan semangat, maka semua penelitiannya tak akan berhasil bahkan siasia. Oleh karena itu, yang menjadi perhatian adalah dengan topik yang telah dikemukakan, maka minatnya haruslah dibangkitkan sebaik-baiknya, agar penelitian dapat diselesaikan sesuai dengan tujuan penelitian. Tentu saja kesuksesan tersebut, haruslah dengan tanpa adanya sesuatu keinginan yang menyimpang. Mendorong timbulnya minat yang kuat tersebut adalah semata-mata berkeinginan untuk "membuktikan kebenaran" bukan merupakan pendapat pribadi yang berkemungkinan hal itu dilakukan tanpa kesengajaan. Dengan demikian, maka akan penelitian dapat dinilai kurang objektif.

\section{B. JENIS PENELITIAN}

Ada beberapa jenis penelitian yang membantu dalam mendefinisikan penelitian. Memang dari beberapa ilmuwan mengklasifikasikan jenis penelitian berbedabeda satu sama lain tetapi pada dasarnya memiliki inti yang tidak jauh berbeda. Ada beberapa klasifikasi untuk membedakan jenis penelitian yang digolongkan menurut sudut pandang tertentu. Menurut Prof. Sutrisno Hadi MA, jenis-jenis penelitian dapat digolongkan sebagai berikut: (1) menurut bidangnya, (2) menurut tempatnya, (3) menurut pemakaiannya, (4) menurut tujuan umumnya, (5) menurut tarafnya, dan (6) menurut pendekatannya (dalam Cholid Narbuko \& Abu Achmadi, 2005: 41). Penelitian menurut bidangnya meliputi penelitian pendidikan, penelitian pertanian, penelitian hukum dan sebagainya. Penelitian menurut tempatnya meliputi penelitian laboratorium, penelitian perpustakaan, dan penelitian kancah. Menurut pemakaiannya, penelitian meliputi penelitian murni (dasar) dan penelitian terapan (terpakai). Menurut tujuan umumnya, penelitian meliputi penelitian eksploratif, penelitian developmental dan penelitian verifikatif. Penelitian menurut tarafnya meliputi penelitian inferensial, sedangkan menurut pendekatannya meliputi penelitian longitudinal dan penelitian cross sectional Penelitian ini dapat diklasifikasikan berdasarkan: (1) aplikasi, (2) maksud, dan (3) jenis informasi yang dikelola (Ronny Kountur, 2004: 103). Berdasarkan aplikasi, penelitian di bagi menjadi dua jenis yaitu penelitian murni dan penelitian terapan, berdasarkan maksud dapat dibagi ke dalam 
tiga jenis yaitu penelitian deskriptif, penelitian korelasi dan penelitian eksperimen. Penelitian murni dilakukan semata-mata untuk keperluan pengembangan dan perbaikan teori den berkaitan dengan penciptaan konsep-konsep umum misalnya tentang pemahaman (learning) (Sumanto, 1995: 6). Penelitian terapan (applied research, practical research) adalah penyelidikan yang hati-hati, sistematik dan terus-menerus terhadap suatu masalah dengan tujuan untuk digunakan dengan segera untuk keperluan tertentu (Nazir, 1988: 30). Penelitian deskriptif yaitu penelitian yang berusaha untuk menuturkan pemecahan masalah yang ada sekarang berdasarkan datadata, jadi ia juga menyajikan data, menganalisis dan menginterpretasi (Cholid Narbuko dan Abu Achmadi, 2005: 44). Penelitian korelasi menunjukan hubungan antara dua atau lebih variabel yang diteliti untuk melihat hubungan yang terjadi tanpa mencoba untuk mengubah atau mengadakan perlakuan terhadap variabel-variabel tersebut (Ronny Kountur, 2004: 104). Penelitian eksperimen yaitu penelitian di mana datanya belum pernah ada, sehingga harus diciptakan terlebih dahulu dan berguna untuk mengembangkan inovasi-inovasi yang berguna dalam meningkatkan kualitas hidup manusia (Gulo, 2002: 21). Jenis penelitian yang akan dibahas di sini adalah yang didasarkan dari jenis informasi yang dikelola yaitu penelitian kuantitatif dan penelitian kualitatif. Jenis penelitian ini umumnya digunakan untuk penulisan skripsi yang biasanya lebih bersifat deskriptif dan korelasi, dan peneltian PTK

\section{a. Penelitian Kuantitatif}

Penelitian dengan metode kuantitatif adalah penelitian yang spesifik, jelas dan terperinci. Tujuan utama dari metodologi kuantitatif ini bukan "menjelaskan" suatu masalah tetapi menghasilkan suatu generaliasi yaitu suatu pernyataan kebenaran yang terjadi dalam suatu realitas tentang suatu masalah yang diperkirakan akan berlaku pada suatu populasi tertentu (Sumanto, 1995: 12). Ada pendapat dari
Kerlinger yang mendefinisikan penelitian kualitatif sebagai suatu bentuk statistik, yaitu : Teori dan metode analisis data kuantitatif yang diperoleh dari sampel observasi untuk mempelajari dan membandingkan sumbersumber varian fenomena; untuk membantu pembuatan keputusan menerima atau menolak hubungan-hubungan antar fenomena yang dihipotesiskan; dan untuk membantu dalam membuat kesimpulankesimpulan yang dapat dipercaya (reliabel) dari observasi-observasi empiris (Hartono, 2003: 79). Jenis data penelitian kuantitatif adalah data kuantitatif yaitu data yang dapat diukur sehingga dapat menggunakan statistik dalam pengujiannya. Desainnya ditentukan secara mantap sejak awal yang menjadi pedoman langkah demi langkah. Penelitian kuantitatif bersifat deduktif yaitu pengambilan kesimpulan dari umum ke khusus. Dikatakan deduktif karena pada awal penelitian telah dikemukakan hipotesis yang diturunkan dari suatu teori dan kemudian diuji kebenarannya berdasarkan data empiris (Nasution, 1988: 14). Penelitian kuantitatif dimulai dengan teori-teori umum yang dibuat suatu konsep yang dirumuskan menjadi hipotesis yang bersifat khusus. Gambaran dari proses deduktif-induktif ini dapat dilihat pada bagan 1 .

Salah satu syarat dalam penelitian kuantitatif ialah bahwa penelitian itu harus dapat diulangi dengan hasil yang sama dalam pengumpulan data. Syarat lain yang mutlak yaitu bacaan yang luas dan up to date (Nasution, 1988: 16). Tanpa literatur yang luas dan mutakhir sebenarnya tidak dapat diadakan penelitian kuantitatif dengan baik. Penelitian kuantitatif didasarkan atas dasar positivisme. Positivisme logis yaitu suatu aliran pemikiran yang menegaskan bahwa semua pengetahuan diperoleh dari observasi langsung dan kesimpulan-kesimpulan logis yang didasarkan pada observasi langsung (Hartono, 2003: 79). 


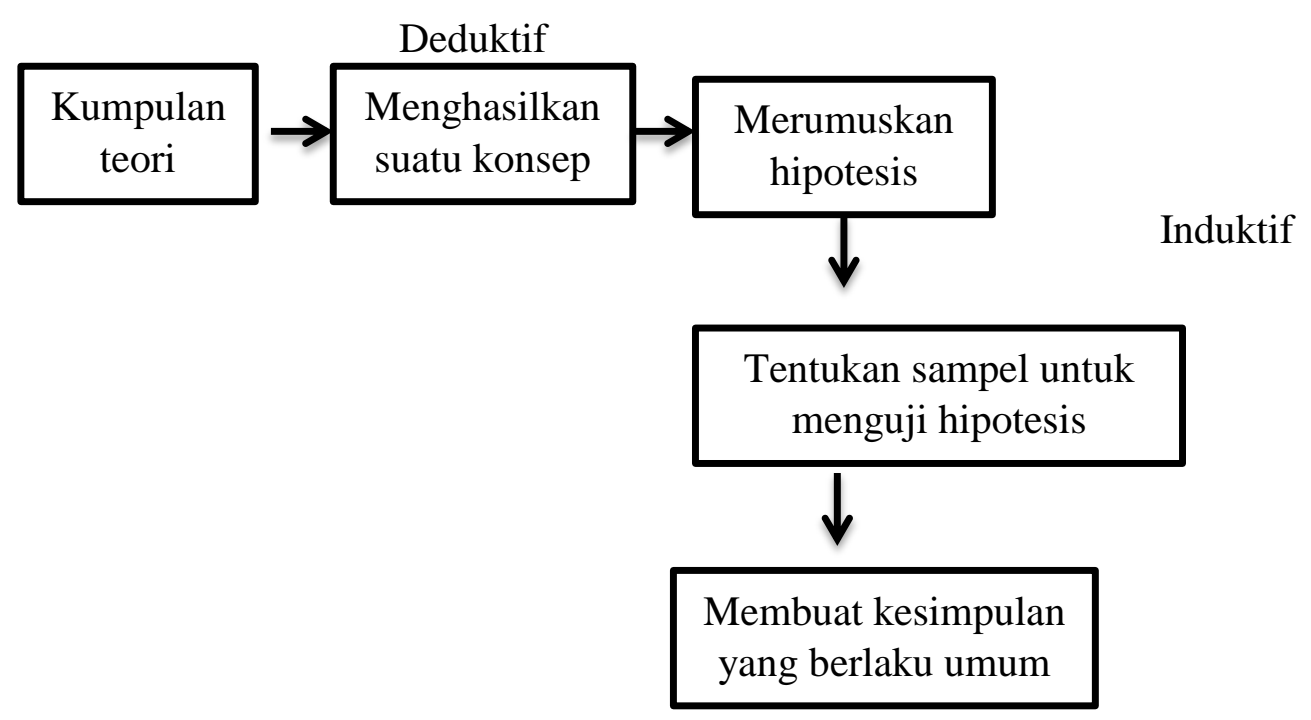

Bagan 1. Proses Deduktif Induktif Penelitian Kuantitatif

(Sumber: Ronny Kountur, 2004:18)

Positivisme berpendirian bahwa kebenaran hanya satu, sama bagi semua orang dan dapat diperoleh dari lingkungan. Peneliti itu objektif, terpisah dari dunia yang diamatinya, serta bebas nilai. Penelitian kuantitatif sering disebut juga dengan istilah paradigma ilmiah (scientific paradigm). Paradigma ilmiah membatasi diri pada pengetahuan proposional. Pengetahuan demikian merupakan esensi metode untuk menyatakan proporsisi secara eksplisit dalam bentuk hipotesis yang diuji untuk menentukan validitasnya (Moleong, 2001: 18). Tabel 1 merupakan beberapa istilah untuk menyebutkan metode kuantitatif dan metode kualitatif.

\begin{tabular}{|l|l|}
\hline \multicolumn{1}{|c|}{ Kuantitatif } & \multicolumn{1}{|c|}{ Kualitatif } \\
\hline Rasionalistik & Naturalistik \\
Penelusuran dari & $\begin{array}{l}\text { Penelusuran dari } \\
\text { luar }\end{array}$ \\
Fungsionalis & Interpretif \\
Positivis & Konstruktivis \\
Positivis & Naturalistik- \\
& Etnografis \\
\hline
\end{tabular}

Tabel 1. Penelitian Kuantitatif dan Kualitatif: Nama-nama Alternatif

(Sumber: Brannen, 2002: 82).

Penelitian yang dibuat dengan menggunakan metode penelitian kuantitatif, yaitu penelitian yang menggunakan statistik dalam pembuktiannya, umumnya terdiri dari lima bab. Bab satu atau bab pendahuluan terdiri dari enam bagian yaitu latar belakang masalah, identifikasi masalah, pembatasan masalah, perumusan masalah, tujuan penelitian, dan manfaat penelitian. Bab dua atau bab landasan teori terdiri dari empat bagian yaitu tinjauan pustaka, hasil penelitian yang relevan (jika ada), kerangka pemikiran, dan perumusan hipotesis (jika ada). Bab tiga atau bab metodologi terdiri dari lima bagian yaitu tempat dan waktu penelitian, metode penelitian, populasi dan sampel, teknik pengumpulan data, dan teknik analisis data. Bab empat atau bab hasil penelitian terdiri dari empat bagian yaitu deskripsi data, pengujian persyaratan analisis, pengujian hipotesis, dan pembahasan hasil analisis data. Bab lima atau bab simpulan, implikasi dan saran terdiri dari tiga bagian yaitu simpulan, implikasi, dan saran.

\section{Penelitian Kualitatif}

Penelitian kualitatif pada hakekatnya ialah mengamati orang dalam lingkungan 
hidupnya, berinteraksi dengan mereka, berusaha memahami bahasa dan tafsiran mereka tentang dunia sekitarnya (Nasution, 1988: 5). Jenis penelitian kualitatif adalah jenis penelitian yang tidak menggunakan statistik, berbeda dengan penelitian kuantitatif. Penelitian kualitatif adalah penelitian yang datanya adalah data kualitatif, umumnya dalam bentuk narasi atau gambar-gambar (Ronny Kountur, 2004: 16). Apabila terdapat data yang berupa angka-angka, hanya menjelaskan sesuatu saja. Penelitian kualitatif lebih tertarik untuk melakukan pemahaman secara mendalam terhadap suatu masalah daripada melihat permasalahan untuk kepentingan generalisasi (Sumanto, 1995: 11). Penelitian kualitatif bersifat empirik dengan sasaran penelitiannya yang sangat beragam permasalahannya yang terjadi sekarang ini. Penelitian sejarah masa lampau, dan juga penelitian filosofis yang biasanya merupakan penelitian kepustakaan meski menggunakan pola pikir kualitatif dari aspek kekinian permasalahan, sering dipandang sebagai penelitian kualitatif yang mempunyai sasaran khusus (Sutopo, 2002: 35). Mahasiswa yang memilih menggunakan metode kualitatif perlu memiliki cukup pengalaman yang peka. Peneliti adalah orang yang hadir di lapangan dengan caranya sendiri jadi cukup penting memahami dan mengetahui apa sebenarnya penelitian kualitatif. Proses penelitian kualitatif mengikuti proses pengambilan simpulan dari khusus ke umum (induktif). Penelitian kualitatif dimulai dengan observasi spesifik dan berlanjut dengan pengembangan pola-pola umum yang muncul dari masalah-masalah yang diteliti. Proses induktif dapat dilihat pada bagan 2 .

Penelitian kualitatif tidak dimaksudkan untuk menguji suatu teori, dan justru kecenderungannya adalah teori akan muncul setelah data-datanya dikumpulkan. Data penelitian kualitatif sangat menarik. Data kualitatif merupakan sumber dari deskripsi yang luas dan berlandasan kokoh, serta memuat penjelasan tentang prosesproses yang terjadi dalam lingkungan setempat. Penelitian kualitatif disebut juga dengan naturalistic inquiry atau inkuiri alamiah. Paradigma alamiah mengizinkan dan mendorong pengetahuan yang diketahui bersama guna dimunculkan untuk keperluan membantu pembentukkan teori (Moleong, 2001: 18). Mengumpulkan data kualitatif merupakan suatu pelaksanaan kerja yang intensif, biasanya memakan waktu berbulanbulan sampai bertahun-tahun. Catatan lapangan dan data yang yang begitu banyak mungkin memerlukan waktu berbulan-bulan sampai bertahun-tahun untuk menganalisisnya secara teliti. Tiga dimensi yang tampak untuk mempertentangkan berbagai metode penelitian kualiatif adalah: (1) masalah dan perihal peneliti, (2) sifat pengetahuan, dan (3) hubungan antara peneliti dengan topik penelitian. Semua metodologi kualitatif sama-sama memiliki tiga asumsi mendasar, yaitu: (1) pandangan holistik, (2) pendekatan induktif, dan (3) penelitian naturalistik (Hartono, 2003: 86). Perbedaan yang menyolok pada susunan laporan skripsi pada penelitian kuantitatif dibandingkan dengan penelitian kualitatif yaitu sub-judul hipotesis dan kerangka penulisan pada bab satu; bab dua tentang obyek penelitian; dan bab tiga tentang prosedur (Ronny Kountur, 2004: 25). Walaupun berbeda, sebenarnya kedua jenis penelitian ini mewakili metodologi penelitian dan dapat saling mengisi. Perbedaanperbedaan yang dirasakan ada oleh para peneliti antara pendekatan kualitatif dan penelitian kuantitatif (apakah perbedaan ini logis ataukah tidak) berpengaruh amat besar pada fokus pelaksanaan proyek-proyek penelitian khususnya pemilihan metode (Brannen, 2004: 12). Berikut adalah tabel perbedaan antara penelitian kuantitatif dengan kualitatif. 


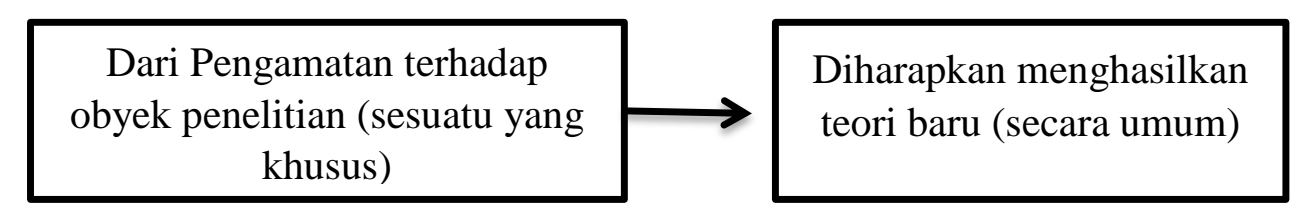

Bagan 2. Proses Induktif Penelitian Kualitatif

(Sumber: Ronny Kountur, 2004: 19).

\begin{tabular}{|l|l|l|}
\hline \multicolumn{1}{|c|}{ Dasar Perbedaan } & \multicolumn{1}{|c|}{ Penelitian Kuantitatif } & \multicolumn{1}{|c|}{ Penelitian Kualitatif } \\
\hline - Jenis data & Kuantitatif & Kualitatif \\
- Proses penelitian & Responden/obyek \\
penelitian & Deduktif-induktif & Induktif \\
- Instrumen & Banyak & Hanya satu yang dijadikan obyek \\
- Tujuan penelitian & $\begin{array}{l}\text { Kuesioner dan instrumen } \\
\text { lainnya } \\
\text { Konfirmasi }\end{array}$ & Peneliti itu sendiri \\
& Eksplorasi \\
\hline
\end{tabular}

Selain perbedaan-perbedaan yang ada pada tabel di atas, perbedaan juga dapat dilihat dari segi desain penelitian yang digunakan. Tabel 3 memberikan gambaran tentang perbedaan desain penelitian kuantitatif dan penelitian kualitatif.

\begin{tabular}{|c|c|}
\hline Desain Penelitian Kuantitatif & Desain penelitian kualitatif \\
\hline Desain terinci dan mantap. & $\begin{array}{l}\text { Desain tidak terinci, fleksibel, timbul } \\
\text { (emergent) serta berkembang sambil jalan } \\
\text { antara lain mengenai tujuan, subyek, sampel, } \\
\text { dan sumber data. }\end{array}$ \\
\hline $\begin{array}{l}\text { Desain direncanakan sebelumnya pada taraf } \\
\text { persiapan (projektif). }\end{array}$ & $\begin{array}{l}\text { Desain sebenarnya baru diketahui dengan } \\
\text { jelas setelah penelitian selesai (retrospektif). }\end{array}$ \\
\hline $\begin{array}{l}\text { Mengemukakan hipotesis sebelumnya, yang } \\
\text { akan diuji kebenarannya. }\end{array}$ & $\begin{array}{l}\text { Tidak mengemukakan hipotesis sebelumnya; } \\
\text { hipotesis lahir sewaktu penelitian dilakukan; } \\
\text { hipotesis berupa "hunches", petunjuk yang } \\
\text { bersifat sementara dan dapat berubah; } \\
\text { hipotesis berupa pertanyaan yang } \\
\text { mengarahkan pada pengumpulan data. }\end{array}$ \\
\hline Hipotesis menentukan hasil yang diharapkan; & $\begin{array}{l}\text { Hasil penelitian terbuka, tidak diketahui } \\
\text { sebelumnya, karena jumlah variabel tidak }\end{array}$ \\
\hline
\end{tabular}




\begin{tabular}{|c|c|}
\hline $\begin{array}{l}\text { hasil telah diramalkan a priori; hasil penelitian } \\
\text { telah terkandung dalam hipotesis. Jumlah } \\
\text { variabel terbatas. }\end{array}$ & terbatas. \\
\hline $\begin{array}{l}\text { Dalam desain jelas langkah-langkah penelitian } \\
\text { serta hasil yang diharapkan. }\end{array}$ & $\begin{array}{l}\text { Desain fleksibel, langkah-langkah tidak } \\
\text { dapat dipastikan sebelumnya dan hasil } \\
\text { penelitian tidak dapat diketahui atau } \\
\text { diramalkan sebelumnya. }\end{array}$ \\
\hline $\begin{array}{l}\text { Analisis data dilakukan setelah semua data } \\
\text { terkumpul, jadi pada tahap akhir }\end{array}$ & $\begin{array}{l}\text { Analisis data dilakukan sejak mulanya } \\
\text { bersamaan dengan pengumpulan data, } \\
\text { walaupun analisis akan lebih banyak pada } \\
\text { tahap-tahap kemudian. }\end{array}$ \\
\hline
\end{tabular}

Tabel 3. Perbandingan Desain Penelitian Kuantitatif dengan Penelitian Kualitatif (Sumber: Nasution, 1988: 28)

\section{Penelitian Tindakan Kelas}

Penelitian Tindakan

research), menghadirkan

(action

suatu

perkembangan bidang penelitian pendidikan yang mengarahkan pengidentifikasian karakteristik kebutuhan pragmatis dari praktisi bidang pendidikan untuk mengorganisir penyelidikan reflektif ke dalam pengajaran di kelas. Penelitian Tindakan adalah suatu proses yang dirancang untuk memberdayakan semua partisipan dalam proses (siswa, guru, dan peserta lainnya) dengan maksud untuk meningkatkan praktek-praktek yang diselenggarakan di dalam pengalaman pendidikan (Hopkin, 1993). Semua partisipan merupakan anggota aktif dalam proses penelitian.

Penelitian tindakan dideskripsikan sebagai suatu penelitian informal, kualitatif, formatif, subjektif, interpretif, reflektif, dan suatu model penelitian pengalaman, dimana semua individu dilibatkan dalam studi sebagai peserta yang mengetahui dan menyokong (Hopkin, 1993). Penelitian tindakan mempunyai tujuan utama menyediakan suatu kerangka penyelidikan kualitatif oleh para guru dan peneliti di dalam situasi pekerjaan kelas yang kompleks.

Beberapa definisi yang diterima secara luas tentang penelitian tindakan adalah sebagai berikut (sebagaimana dikutip oleh Dan MacIsaac, 1996: 1):

- Penelitian Tindakan dapat diarahkan untuk memberikan kontribusi pada perhatian praktis dari orang-orang dalam suatu situasi problematik langsung dan pada tujuan-tujuan ilmu sosial dengan hubungan kolaborasi di dalam suatu kerangka kerja etik yang dapat diterima (dalam Hopkin, 1985).

- Penelitian Tindakan adalah suatu bentuk penelitian refleksi diri (selfreflective) yang dilaksanakan oleh para partisipan dalam situasi-situasi sosial (termasuk pendidikan) dalam rangka meningkatkan (a) keadilan dan rasionalitas praktek-praktek sosial dan pendidikan mereka sendiri, (b) pemahaman mereka tentang praktek-praktek tersebut, dan (c) situasi-situasi tempat praktek-praktek tersebut dilaksanakan. Itu sangat rasional bila dilakukan oleh para partisipan (Kemmis yang dikutip oleh Hopkin, 1985).

- Penelitian Tindakan adalah studi sistematis dari upaya-upaya untuk meningkatkan praktek pendidikan oleh kelompok-kelompok partisipan dengan cara tindakan-tindakan praktis mereka sendiri dan dengan cara 
refleksi mereka sendiri terhadap pengaruh-pengaruh tindakan-tindakan tersebut (Hopkin, 1985 dalam MacIsaac, 1996: 1).

Kerangka kerja penelitian tindakan adalah yang paling sesuai untuk para partisipan yang mengenali eksistensi kekurangan-kekurangan dalam aktivitasaktivitas pendidikan mereka dan yang bermaksud mengadopsi beberapa pendirian awal yang berhubungan dengan masalah, merumuskan suatu rencana, melaksanakan suatu intervensi, mengevaluasi hasilnya, dan mengembangkan strategi lebih lanjut dalam suatu pertunjukan berulang-ulang (iterative fashion) (Hopkin, 1993 dalam Dan MacIsaac, 1996: 1).

\section{KECENDERUNGAN PENELITIAN PENDIDIKAN}

Kecenderungan penelitian pendidikan selalu mengalami perubahan dari waktu ke waktu khususnya di penelitian pendidikan bahasa di bidang bahasa Arab sebagai jurusan yang menginginkan lulusanya dapat dimanfaatkan oleh stage holder dan bisa sesuai dengan keinginan stage holder. Perubahan ini mengikuti perkembangan fenomena permasalahan dalam dunia pendidikan yang sedang berkembang di lapangan. Beberapa perubahan cenderung memusat pada metode penelitian (White , 1977). Jenis penelitian ini memusatkan penelitiannya pada metodologi penelitian yang mengalami pergeseran dari penelitian eksperimental menjadi penelitian deskriptif dari data yang dikumpulkan baik melalui wawancara maupun observasi, White (1977) juga menambahkan beberapa topik cenderung menghilang dan topik tertentu cenderung muncul kembali.

Duit (2007) juga menyatakan bahwa telah terjadi perubahan fokus subyek penelitian dari era ke era berikutnya, dan pada saat ini cenderung memusat pada pendekatan kontruktifisme, kontektual, dan pragmatis, sedangkan Jenkin(2001) mengungkap bahwa tren penelitian yang berfokus pada penelitian yang berhubungan dengan aspek guru, anak didik, buku teks, pedagogis, kurikulum, dan evaluasi cenderung berupaya mengadakan pembaharuan sistem pendidikan yang lebih baik.

\section{Desain Penelitian}

Penelitian ini dilaksanakan di Jurusan Bahasa Dan Sastra Arab FBS UNJ pada semester genap tahun 2012-2013 dan sebagai subyeknya adalah hasil penelitian mahasiswa atau skripsi selama kurun 5 tahun terakhir.

Penelitian ini bermaksud untuk mengidentifikasi, menganalisis, dan memetakan hasil-hail penelitian mahasiswa selama kurun waktu 5 tahun terakhir.

Adapun langkah-langkahnya yang akan dilakukan peneliti adalah sebagai berikut :

1. Peneliti mendaftar semua hasil penelitian mahasiswa (skripsi) selama kurun waktu 5 tahun dengan mengelompokkan per tahun

2. Peneliti mengelompokkan skripsi dalam setiap bidang kajian

3. Peneliti mengalisis setiap bidang kajian skripsi

4. Peneliti kemudian menarik kesimpulan dari setiap unsur yang timbul pada tiap bidang kajian.

Penelitian diharapkan ini dapat memberi kontribusi pada JBSA dalam membuat persetujuan usulan judul skripsi pada mahasiswa tahun akhir, dengan mempertimbangkan dengan skripsi yang sudah ditulis oleh mahasiswa angkatan sebelumnya.

\section{HASIL PENELITIAN DAN PEMBAHASAN}

Dengan melalui tahapan seperti apa yang dijelaskan di atas, yaitu penelitian ini mengikuti langkah-langkah yang telah dilakukan peneliti adalah sebagai berikut

1. Peneliti mendaftar semua hasil penelitian mahasiswa (skripsi) selama kurun waktu 5 tahun dengan mengelompokkan per tahun

2. Peneliti mengelompokkan skripsi dalam setiap bidang kajian

3. Peneliti mengalisis setiap bidang kajian skripsi 
4. Peneliti kemudian menarik kesimpulan dari setiap unsur yang timbul pada tiap bidang kajian.

Dalam penelitian ini, peneliti telah mengumpulkan hasil skripsi yang ditulis oleh mahasisiswa JBSA selama kurun waktu 5 tahun yaitu dari tahun 2008 sampai 2012, dengan kode semester 089 sampai 098 telah menghasilkan skripsi dan makalah ujian komprensif sejumlah 321 yang tersebar di 10 semester dengan rincian sebagai berikut, seperti dalam tabel:

\begin{tabular}{|l|l|l|}
\hline No. & Semester & Jumlah skripsi \\
\hline 1. & 089 & 34 buah \\
\hline 2. & 090 & 24 buah \\
\hline 3. & 091 & 17 buah \\
\hline 4. & 092 & 21 buah \\
\hline 5. & 093 & 21 buah \\
\hline 6. & 094 & 38 buah \\
\hline 7. & 095 & 35 buah \\
\hline 8. & 096 & 57 buah \\
\hline 9. & 097 & 37 buah \\
\hline 10. & 098 & 37 buah \\
\hline & Total & 321 buah \\
\hline
\end{tabular}

Untuk lebih jelasnya bisa dilhat dalam grafik ini

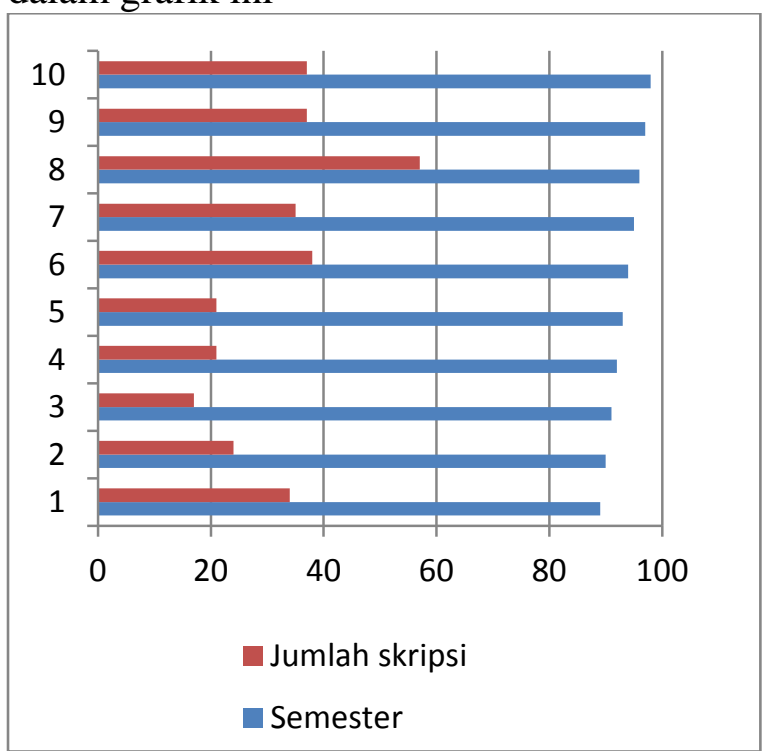

Dengan demikian dalam sepuluh semester Jurusan Bahasa dan Satra Arab telah menghasilkan 321 skripsi dengan rata rata setiap semester menghasilkan skripsi antara 32 sampai 33 buah. Jumlah tersebut bila dirasiokan dengan penerimaan mahasiswa setiap semesternya, Jurusan Bahasa dan Sastra Arab berarti meluluskan mahasiswanya setiap semester mencapai \pm 90\% dari jumlah penerimaan mahasiswa setiap tahunnya

\section{A. PEMBAHASAN}

Skripsi yang dihasilkan JBSA dalam kurun waktu 5 tahun tersebut tersebar dalam berbagai bidang kajian penelitian, yang meliputi; penelitian kualitatif sejumlah 151 buah skripsi, penelitian kuantitatif sejumlah 100 buah skripsi, penelitian tindakan 62 buah skripsi,dan makalah ujian komprehesif 8 buah makalah. Dengan dengan rincian prosentase seperti dalam tabel berikut :

\begin{tabular}{|l|l|l|l|}
\hline No & $\begin{array}{l}\text { Jumlah } \\
\text { skripsi }\end{array}$ & Jumlah & Prosentase \\
\hline 1. & $\begin{array}{l}\text { Penelitian } \\
\text { kualitatif }\end{array}$ & 151 & $47 \%$ \\
\hline 2. & $\begin{array}{l}\text { Penelitian } \\
\text { kuntitatif }\end{array}$ & 100 & $31 \%$ \\
\hline 3. & $\begin{array}{l}\text { Penelitian } \\
\text { Tindakan }\end{array}$ & 62 & $19 \%$ \\
\hline 4 & $\begin{array}{l}\text { Makalah } \\
\text { komprehensif }\end{array}$ & 8 & $3 \%$ \\
\hline & Jumlah & 321 & $100 \%$ \\
\hline
\end{tabular}

Tabel hasil penelitian.

Penelitian mahasiswa JBSA yang dihasilkan dari penelitian kualitatif sejumlah 151 buah itu berupa analisis isi dari gejala bahasa atau hasil karya sastra yang dikaji melalui kajian teoretik gejala atau fenomena bahasa, dari penelitian kuantitatif menghasilkan 100 buah yaitu $31 \%$ tersebut berupa kajian uji korelasional 40 buah skripsi, uji eksperimen 35 buah skripsi, dan uji kausal komparatif menghasilkan 25 buah 
skripsi. Sedangkan Penelitian tindakan hanya didapatkan 2 macam tindakan yaitu penggunaan media pembelajaran dan penggunaan metode dalam pembelajaran, dari dua tindakan tersebut menghasilkan dalam penggunaan media Pembelajaran sejumlah 35 buah skripsi dan dalam penggunaan metode pembelajaran menghasilkan 27 buah skripsi, itulah sebaran skripsi yang ditulis mahasiswa JBSA selama kurun waktu 5 tahun.

Dari hasil paparan di atas menunjukkan bahwa bidang penelitian skripsi yang ditulis mahasiswa JBSA, masih banyak yang belum dilakukan oleh mahasiswa khususnya dalam kajian bahasa dalam isu isu baru dalam pendidikan.

\section{SIMPULAN}

Dari hasil pembahasan yang telah dilakukan peneliti, bahwa bila dilihat dari rasio hasil skripsi yang dihasilkan setiap semester terhadap penerimaan mahasiswa setiap tahun, Jurusan Bahasa dan Sastra masih menunjukkan angka keberhasilan yang diperoleh $\pm 90 \%$. perolehan ini menunjukkan bahwa sebaran mata kuliah setiap semester memungkinkan bagi mahasiswa untuk menyelesaikan masa studi tepat waktu yaitu dalam waktu 8 semester, sehingga JBSA secara akreditasi dapat dinilai berhasil.

Variasi dan sebaran kajian mahasiswa dalam penelitian sudah cukup merata dalam berbagai jenis penelitian, baik itu penelitian kualitatif maupun kuantitatif ataupun penelitian tindakan. Walaupun kajian dalam penelitian kualitatif dan kuantitatif masih belum banyak semua dikaji, tetapi bila penelitian mahasiswa JBSA itu dilihat dari kemampuan mahasiswa strata 1 dinilai sudah cukup dan hasil penelitian mahasiswa S1 JBSA masih bisa dilanjutkan sebagai penelitian lanjutan. Dengan demikian mahasiswa JBSA telah memenuhi kriteria dalam memilih topik penelitian sesuai dengan ketertarikan dan kemampuan mereka.

Penelitian mahasiswa JBSA bila dilihat dari jenis penelitian kualitatif masih dalam taraf analisis deskriptif dan kuantitatif masih dalam uji analisis, baik kuantitatif maupun kualitaif belum sampai pada taraf uji prediksi ataupun aplikasi, sehingga masih memungkinkan seorang mahasiswa memperdalam penelitian dari penelitian yang sudah dilakukan oleh mahasiswa sebelumnya.

\section{Referensi}

Ar, Syamsuddin dan Vismaia S. Damianti. Metode Penelitian Pendidikan Bahasa. Bandung:Remaja Rosdakarya. 2009.

Creswell. Educational Research: Planning, Conducting, and Evaluating Quantitative and Qualitative Research. New Jersey:Pearson Education. 2008.

Dellsl, How to use problem-based learning in the classroom. Alexandria, VA: Assosiation for supervision and curriculum Develompment1977.

Emzir. Metodologi Penelitian Analisis Data. Jakarta:Raja Grafindo Persada. 2010.

Fraenkel, J.R., \& Wallen, N.E. How to Design and Evaluate Research in Education. New York: McGraw-Hill Publishing Company. 1990.

Gay, L.R. dkk. Educational Research: Competencies for Analysis and Applications. New Jersey:Pearson Education. 2009.

Hermawan, Budi. 2007. Metodologi Penelitian. Cianjur:LPPM-YPPI.

Kountur, Ronny. Statistik Praktis. Jakarta:PPM. 2006.

Narbuko, Cholid dan Abu Achmadi. Metodologi Penelitian. Jakarta:Bumi Aksara. 2009.

Nazir, Moh. Metode Penelitian. Bogor: Ghalia Indonesia. 2005.

Prastowo, Andi. Memahami Metode-metode Penelitian. Jogjakarta:Ar-Ruzz Media. 2011. 
Silalahi, Ulber. Metode Penelitian Sosial. Bandung:Refika Aditama. 2010.

Subana, M dan Suddrajad. Dasar-dasar Penelitian Ilmiah. Jakarta:Pustaka Setia. 2005.

Subroto, Edi. Pengantar Metode Penelitian Linguistik Struktural. Surakarta:UNS Press. 2007.

Sugiono. Metode Penelitian Pendidikan. Bandung:Alfabeta. 2007.

Sukardi. Metodologi Penelitian Pendidikan. Jakarta: Bumi Aksara. 2011.

Surakhmad, Winarno. Pengantar Penelitian Ilmiah: Dasar, Metode, dan Teknik. Bandung:Tarsito. 1994.
Suryabrata, Sumadi. Metodologi Penelitian. Jakarta:Raja Grafindo Persada. 2005.

T.Widodo. Metode Penelitian Kuantitatif. Surakarta:Lembaga Pengembangan Pendidikan. 2008.

Verduin , J. Helping Student Develop investigative Problem Solving Thingking Skills in a Cooperatif Setting. Springfield, IL: C.C Thomas 1996

White, R.. Trends in research in Science Education, Research in Science Education .27(2), 1997 